ISSN: 2224-0616

Int. J. Agril. Res. Innov. \& Tech. 3 (1): 5-11, J une, 2013 Available online at http:/ / www.ijarit.webs.com

\title{
ADOPTION OF SELECTED WHEAT PRODUCTION TECHNOLOGIES IN TWO NORTHERN DISTRICTS OF BANGLADESH
}

\author{
M.S. Rahman' ${ }^{1}$ and Zerina Haque ${ }^{2}$
}

Received 21 December 2012, Revised 28 May 2013, Accepted 20 June 2013, Published online 30 June 2013

\begin{abstract}
The study was conducted in two major wheat growing areas of Bangladesh to determine the adoption level and factors affecting the adoption of wheat production practices in the study areas during 2011. Descriptive statistics along with multiple regression technique was used to achieve the objectives. The results revealed that most of the farmers (60.91\%) in the study areas were cultivating Shatabdi variety of wheat. Adoption level of seed rate, TSP and MoP application were found to be very low. On the other hand, production practices like time of wheat sowing and number of irrigation were highly adopted by the farmers. Most of the farmers (69.09\%) applied TSP below the recommended dose while $81.82 \%$ of the farmers applied MoP over the recommended dose. The study also revealed a positive and significant relationship between adoption and the variables like education, experience and extension contact. Lack of proper information and technical knowledge were the major problems that hinder the adoption of wheat production technologies in the study areas. Adoption gaps are needed to be eliminated to enhance the productivity as well as net return of wheat cultivation.
\end{abstract}

Keywords: Adoption, Production Technology, Northern Bangladesh

${ }^{1}$ Assistant Professor, Department of Management and Finance, Faculty of Agribusiness Management, Sher-e Bangla Agricultural University, Dhaka, Bangladesh

${ }^{2}$ Ex-MS Student, Bangabandhu Sheikh Mujibur Rahman Agricultural University, Salna, Gazipur, Bangladesh

*Corresponding author's email: saadrhmn@yahoo.com (M.S. Rahman)

\section{Introduction}

Agriculture is the backbone of the economy of Bangladesh. Climate of Bangladesh is strongly favorable for different crop production. However, most of the farmers of the country still follow the traditional crop production technologies (Pandit et al., 2007). Therefore, they receive lower yield and cannot meet the food demand of the country. Thus, the technology adoption by the farmers is an essential pre-requisite for economic prosperity in developing country likes Bangladesh. Adoption may be defined as the integration of an innovation into farmers' normal farming activities over an extended period of time (Feder et al., 1985). Increasing population pressures, traditional farming systems and small farm holding are not enough to support growing number of people in household. Whereas, the one who adopts improved crop production packages can produce ample food for as many as thousands of people. Successful adoption of improved agricultural technologies could stimulate overall economic growth through inter sectoral linkages while conserving natural resources (Sanchez et al., 2009). Past studies (Dixon et al., 2006; Wanyama et al., 2010) showed that adoption of improved production practices may help the farmers to get higher amount of yield and had impact on household food security and income.
An important objective of rural development is to increase agricultural productivity with a view to enhancing farmer's income and standard of living. Improved practices provide the main venue for increasing productivity in the country's agriculture (Edna et al., 2009). Rural development can be promoted through stimulating the adoption of improved production practices. Bangladesh Agricultural Research Institute has developed improved production practices for various crops. However, this study only considered the wheat crop as it is one of the most important cereal crops in Bangladesh. It is grown on about 3,764,24 hectares of land with an average production of 9,01,490 MT (BBS, 2010). At present, high-yielding varieties occupy $98 \%$ of the area (Hossain, 1984). Still every year Bangladesh needs to import large amount of wheat grains to meat up local demand of about 3.5 million ton (Baksh et al., 2009). Several studies at home and abroad (Hossain and Bruce, 1992; Kamruzzaman et al., 2001; Iqbal Muhammad et al., 2002; Walford, 2002; Lee David, 2005; Gardebroek, 2006; Serra et al., 2008; Baksh et al., 2009; Singh and Chahal, 2009) have been conducted on the adoption of different agricultural technology and crop variety. However, very few of them considered the adoption level of production practices of wheat in Bangladesh. Keeping all these factors in 
consideration the study was undertaken with the following specific objectives.

\section{Specific objectives}

i. To determine the level of adoption of improved wheat production practices

ii. To find out the factors affecting the adoption decision and

iii. To identify the problems that limits the acceptability of improved wheat production practices.

\section{Materials and Methods}

Two major wheat growing districts of Bangladesh namely Dinajpur and Thakurgaon were purposively selected for the study. A total of 110 sample taking 55 from each district were selected for the study by using random sampling technique. The study was mainly based on primary data collected through face to face interview during the month of February to April, 2011. Collected data were then summarized, tabulated and analyzed to fulfill the objectives of the study.

\section{Analytical technique}

Mostly descriptive statistics like average percentage were used to achieve the objectives of the study. Adoption level of wheat production practices were evaluated against the recommended doses given in Krishi Projukti Hatboi (2006) published by Bangladesh Agricultural Research Institute.

\section{Calculation of adoption level}

The level of adoption was measured by computing adoption scores for recommended technologies. Scores given to each technology that varied from 1 to 0 according to the adoption of the suggested technology. A respondent farmer could get a score of " 1 " for adopting the technology. On the other hand, farmer could receive a score of " 0 " for not adopting the technology. The mean score became the index of level adoption of the recommended technologies. On the basis of the score that earned by the farmers were categorized as high, medium, low and very low level of adoption respectively.

\section{Multiple regression analysis}

To find out the factors responsible for adoption of wheat production practices a multiple regression analysis was conducted considering pooled adoption scores of a farmer as dependent variable. Following type of multiple regression model was used for this study;

$\mathrm{Y}=\beta_{0}+\beta_{1} \mathrm{x}_{1}+\beta_{2} \mathrm{x}_{2}+\beta_{3} \mathrm{X}_{3}+\beta_{4} \mathrm{x}_{4}+\beta_{5} \mathrm{x}_{5}+\beta_{6} \mathrm{x}_{6}+\mathrm{u}_{\mathrm{i}}$

Where,

$\mathrm{Y}=$ Pooled adoption score

$\mathrm{X}_{1}=$ Education (Year of schooling)

$\mathrm{X}_{2}=$ Age of the respondent (years)

$\mathrm{X}_{3}=$ Experience is farming (years)

$\mathrm{X}_{4}=$ Farm size (ha)

$\mathrm{X}_{5}=$ Household size (Actual number of members of the household)

$\mathrm{X}_{6}=$ Extension contact (score)

$\mathrm{u}_{\mathrm{i}}=$ Error term

\section{Results and Discussion}

\section{Socio-economic profile of the respondents}

It is revealed from Table 1 that average age of respondents was more or less similar in both the study areas. About $83 \%$ of the respondents were literate in the study areas. Most of them (39.09\%) had secondary level of education. Average family size was found to be 5.78 which was higher than the national average. Average farm size of Thakurgaon (1.59 ha) was found higher compared to Dinajpur district (1.47 ha). Farmers of Dinajpur were more experienced in wheat farming than that of Thakurgaon. Average experience in wheat farming was found to be 13.74 years in all areas.

Table 1. Profile of the respondents

\begin{tabular}{llll}
\hline Items & $\begin{array}{l}\text { Dinajpur } \\
(\mathrm{n}=55)\end{array}$ & $\begin{array}{l}\text { Thakurgaon } \\
(\mathrm{n}=55)\end{array}$ & $\begin{array}{l}\text { All areas } \\
(\mathrm{n}=110)\end{array}$ \\
\hline $\begin{array}{l}\text { Demographic Characteristics } \\
\text { Average age of respondents (yrs ) }\end{array}$ & $41(12.7)$ & $40(10.4)$ & $40(11.5)$ \\
Level of education (\%) & -10.91 & - & - \\
Illiterate & 34.55 & 21.82 & 16.36 \\
Primary & 34.55 & 43.82 & 28.18 \\
Up to SSC & 16.36 & 9.09 & 39.09 \\
HSC & 3.64 & 3.64 & 12.73 \\
Above HSC & $5.80(2)$ & $5.76(2.5)$ & 3.64 \\
Average Family size (No/ family) & - & - & - \\
Land use (ha) & $1.18(1.1)$ & $1.32(1.9)$ & $1.25(1.6)$ \\
Own cultivated land & $1.47(1.1)$ & $1.59(1.9)$ & $1.53(1.5)$ \\
Average farm size & $0.39(0.3)$ & $0.44(0.6)$ & $0.42(0.5)$ \\
Wheat cultivated area & $14.65(6.3)$ & $12.96(5.7)$ & $13.81(6)$ \\
Experience in wheat cultivation (yrs) & &
\end{tabular}

Note: Figures in the parentheses indicates standard deviation 


\section{Farmers growing different varieties}

Majority $60.91 \%$ of the farmers in both of the study areas were grown Shatabdi variety followed by Prodip (34.55\%). More than $67 \%$ of the farmers in Thakurgaon grown Shatabdi variety while it was about $54.55 \%$ in Dinajpur district (Table 2).

Table 2. Distribution of farmers according to prevailing wheat varieties in the study area

\begin{tabular}{llll}
\hline Variety name & $\begin{array}{l}\text { Dinajpur } \\
(\mathrm{n}=55)\end{array}$ & $\begin{array}{l}\text { Thakurgaon } \\
(\mathrm{n}=55)\end{array}$ & $\begin{array}{l}\text { Both areas } \\
(\mathrm{n}=110)\end{array}$ \\
\hline Prodip & 45.45 & 23.63 & 34.55 \\
Shatabdi & 54.55 & 67.27 & 60.91 \\
Showrab & - & 9.09 & 4.55 \\
\hline
\end{tabular}

Seed rate

It was found that majority (87\%) of the respondents' exceded the recommended amount of seed (120 kg ha-1). None of the farmers applied the seed lower than the recommended dose. Only
$12.73 \%$ of the respondents were using recommended quantity of seed. The mean score of adoption was found only 0.13 which indicates very low level of adoption in both the areas (Table 3).

Table 3. Seed rate of wheat used by the sample farmers in the study areas

\begin{tabular}{llllll}
\hline Location & $\begin{array}{l}\text { Recommended } \\
\text { rate }\end{array}$ & $\begin{array}{l}\text { Above } \\
\text { recommended } \\
\text { rate }\end{array}$ & $\begin{array}{l}\text { Below } \\
\text { recommended } \\
\text { rate }\end{array}$ & Mean & $\begin{array}{l}\text { Adoption } \\
\text { level* }\end{array}$ \\
\hline Dinajpur $(\mathrm{n}=55)$ & $7(12.73)$ & $48(87.27)$ & - & 0.13 & Very low \\
Thakurgaon $(\mathrm{n}=55)$ & $7(12.73)$ & $48(87.27)$ & - & 0.13 & Very low \\
All areas $(\mathrm{n}=110)$ & $14(12.73)$ & $96(87.27)$ & - & 0.13 & Very low \\
\hline
\end{tabular}

Note: Figures in parentheses indicates percentage of total

*Adoption level was categorized for mean score $\leq 0.25$ as very low, between 0.26 to 0.50 as low, between 0.51 to 0.75 as medium and between 0.76 to 1.00 as high

\section{Time of sowing}

It is evident from Table 4 that most of the farmers were sowing wheat crop during the recommended period ( $2^{\text {nd }}$ week of Nov. to $1^{\text {st }}$ week of Dec.). More than $85 \%$ of the farmers sowing wheat crop during the recommended period while about $14 \%$ of the farmers sowing wheat after the recommended period. Mean score of adoption was found 0.85 which indicated high level of adoption.

Table 4. Time of wheat crop sowing in the study areas

\begin{tabular}{lllll}
\hline Location & $\begin{array}{l}\text { During } \\
\text { recommended } \\
\text { period }\end{array}$ & $\begin{array}{l}\text { After } \\
\text { recommended } \\
\text { period }\end{array}$ & Mean & $\begin{array}{l}\text { Adoption } \\
\text { level* }\end{array}$ \\
\hline Dinajpur $(\mathrm{n}=55)$ & $47(85.45)$ & $8(14.55)$ & 0.85 & High \\
Thakurgaon $(\mathrm{n}=55)$ & $47(85.45)$ & $8(14.55)$ & 0.85 & $\begin{array}{l}\text { High } \\
\text { All areas }(\mathrm{n}=110)\end{array}$ \\
\hline
\end{tabular}

Note: Figures in parentheses indicates percentage of total

*Adoption level was categorized for mean score $\leq 0.25$ as very low, Between 0.26 to 0.50 as low, between 0.51 to 0.75 as medium and between 0.76 to 1.00 as high

\section{Seed treatment}

It is revealed from the Table 5 that almost all the farmers did not treat the seed before sowing wheat. More than $96 \%$ of the farmers did not treat wheat seed before sowing in Thakurgaon while it was $91 \%$ in Dinajpur district. Therefore, there exists a scope for filling the gap in the adoption of this technology. It will not only protect the crop from primary diseases infestation but will also augment the productivity of wheat in the study areas. 
Table 5. Percentage of farmers adopting seed treatment

\begin{tabular}{llll}
\hline Items & Dinajpur $(\mathrm{n}=55)$ & Thakurgaon $(\mathrm{n}=55)$ & All areas $(\mathrm{n}=110)$ \\
\hline Yes & 9.09 & 3.64 & 6.36 \\
No & 90.91 & 96.36 & 93.64 \\
\hline
\end{tabular}

\section{Fertilizer application}

\section{Urea}

It is evident from Table 6 that $39.09 \%$ of the farmers used recommended dose of urea (180$220 \mathrm{~kg} \mathrm{ha}^{-1}$ ). About 32\% of the farmers used urea

Table 6. Application of urea by the sample farmers over the recommended level and $29 \%$ farmers used urea lower than the recommended dose. Overall adoption score of urea was found 0.39, which indicated low level of adoption.

\begin{tabular}{llllll}
\hline Locations & $\begin{array}{l}\text { Recommended } \\
\text { dose }\end{array}$ & $\begin{array}{l}\text { Above } \\
\text { recommended } \\
\text { dose }\end{array}$ & $\begin{array}{l}\text { Below } \\
\text { recommended } \\
\text { dose }\end{array}$ & Mean & $\begin{array}{l}\text { Adoption } \\
\text { level* }\end{array}$ \\
\hline Dinajpur $(\mathrm{n}=55)$ & $21(38.18)$ & $20(36.36)$ & $14(25.45)$ & 0.38 & Low \\
Thakurgaon $(\mathrm{n}=55)$ & $22(40.00)$ & $15(27.27)$ & $18(32.73)$ & 0.40 & Low \\
All areas $(\mathrm{n}=110)$ & $43(39.09)$ & $35(31.82)$ & $32(29.09)$ & 0.39 & Low \\
\hline
\end{tabular}

Note: Figures in parentheses indicates percentage of total

*Adoption level was categorized for mean score $\leq 0.25$ as very low, between 0.26 to 0.50 as low, between 0.51 to 0.75 as medium and between 0.76 to 1.00 as high

TSP

Most of the farmers (69.09\%) used TSP lower than the recommended dose (140-180 kg ha-1). Only $20.91 \%$ of the farmers used recommended dose of TSP. Overall adoption score of TSP application was found 0.21 . It indicated very low level of adoption.

Table 7. Application of TSP by the sample farmers

\begin{tabular}{llllll}
\hline Location & $\begin{array}{l}\text { Recommended } \\
\text { dose }\end{array}$ & $\begin{array}{l}\text { Above } \\
\text { recommended } \\
\text { dose }\end{array}$ & $\begin{array}{l}\text { Below } \\
\text { recommended } \\
\text { dose }\end{array}$ & Mean & $\begin{array}{l}\text { Adoption } \\
\text { level* }\end{array}$ \\
\hline Dinajpur $(\mathrm{n}=55)$ & $11(20.00)$ & $4(7.27)$ & $40(72.73)$ & 0.20 & Very low \\
Thakurgaon $(\mathrm{n}=55)$ & $12(21.82)$ & $7(12.73)$ & $36(65.45)$ & 0.22 & Very low \\
All areas $(\mathrm{n}=110)$ & $23(20.91)$ & $11(10.00)$ & $76(69.09)$ & 0.21 & Very low \\
\hline
\end{tabular}

Note: Figures in parentheses indicates percentage of total

*Adoption level was categorized for mean score $\leq 0.25$ as very low, between 0.26 to 0.50 as low, between 0.51 to 0.75 as medium and between 0.76 to 1.00 as high

MoP

About $86 \%$ of the farmers of Thakurgaon applied MoP more than the recommended dose (40-50 kg ha $^{-1}$ ) whereas more than $78 \%$ of the farmers of Dinajpur used MoP more than the recommended dose. On an average, about $82 \%$ of the farmers applied MoP more than the recommended dose. Only $13.64 \%$ of the farmers applied recommended dose of MoP. As a result adoption level of MoP application found to be very low in the study areas with an adoption score of only 0.14 (Table 8).

Table 8. Application of MoP by the sample farmers

\begin{tabular}{llllll}
\hline Location & $\begin{array}{l}\text { Recommended } \\
\text { dose }\end{array}$ & $\begin{array}{l}\text { Above } \\
\text { recommended } \\
\text { dose }\end{array}$ & $\begin{array}{l}\text { Below } \\
\text { recommended } \\
\text { dose }\end{array}$ & Mean & $\begin{array}{l}\text { Adoption } \\
\text { level* }\end{array}$ \\
\hline Dinajpur $(\mathrm{n}=55)$ & $8(14.55)$ & $43(78.18)$ & $4(7.27)$ & 0.15 & Very low \\
Thakurgaon $(\mathrm{n}=55)$ & $7(12.73)$ & $47(85.45)$ & $1(1.82)$ & 0.13 & Very low \\
All areas $(\mathrm{n}=110)$ & $15(13.64)$ & $90(81.82)$ & $5(4.55)$ & 0.14 & Very low \\
\hline
\end{tabular}

Note: Figures in parentheses indicates percentage of total

*Adoption level was categorized for mean score $\leq 0.25$ as very low, between 0.26 to 0.50 as low, between 0.51 to 0.75 as medium and between 0.76 to 1.00 as high 


\section{Top dressing of urea}

Almost 85\% of the farmers applied top dressing of urea within the recommended period (at the time of first irrigation). Only $15 \%$ of the farmers

Table 9. Time of top dressing of Urea in the study areas

\begin{tabular}{lllll}
\hline Location & $\begin{array}{l}\text { During } \\
\text { recommended } \\
\text { period }\end{array}$ & $\begin{array}{l}\text { After } \\
\text { recommended } \\
\text { period }\end{array}$ & Mean & Adoption level* \\
\hline Dinajpur $(\mathrm{n}=55)$ & $48(87.27)$ & $7(12.73)$ & 0.87 & High \\
Thakurgaon $(\mathrm{n}=55)$ & $45(81.82)$ & $10(18.18)$ & 0.82 & High \\
All areas $(\mathrm{n}=110)$ & $93(84.55)$ & $17(15.45)$ & 0.85 & High \\
\hline
\end{tabular}

Note: Figures in parentheses indicates percentage of total

*Adoption level was categorized for mean score $\leq 0.25$ as very low, between 0.26 to 0.50 as low, between 0.51 to 0.75 as medium and between 0.76 to 1.00 as high

\section{Number of irrigation}

The recommended number of irrigation to wheat crop is 2-3 times depending on the type of soil (Krishi Projukti Hatboi, 2006). The present study had found that $83.64 \%$ of the farmers applied recommended number of irrigation while about $16 \%$ of the farmers applied less than the recommended number of irrigation. Overall adoption level of irrigation number was found to be high in the study areas.

Table 10. Number of irrigations applied by the sample farmers

\begin{tabular}{llllll}
\hline Location & Recommended & $\begin{array}{l}\text { Above } \\
\text { recommended }\end{array}$ & $\begin{array}{l}\text { Below } \\
\text { recommended }\end{array}$ & Mean & $\begin{array}{l}\text { Adoption } \\
\text { level* }\end{array}$ \\
\hline Dinajpur $(\mathrm{n}=55)$ & $44(80.00)$ & $1(1.82)$ & $10(18.18)$ & 0.80 & $\begin{array}{l}\text { High } \\
\text { Thakurgaon }(\mathrm{n}=55)\end{array}$ \\
All areas $(\mathrm{n}=110)$ & $92(87.27)$ & - & $7(12.73)$ & 0.87 & High \\
\hline
\end{tabular}

Note: Figures in parentheses indicates percentage of total

*Adoption level was categorized for mean score $\leq 0.25$ as very low, between 0.26 to 0.50 as low, between 0.51 to 0.75 as medium and between 0.76 to 1.00 as high

\section{Factors affecting the adoptions}

Results of the regression analysis showed that $51 \%$ of variation in adoption could be explained by the independent variables included in the model. The co-efficient of education, experience and extension contact were significant and positively related with the adoption of wheat production practices. Coefficient of education implies that respondent with higher education adopted more. This agrees with the findings of Mittal Surabhi and Praduman Kumar (2000). Similarly, Coefficient of extension contact suggests that the more the extension contact with the farmers, the more information on the improved wheat production practices reach to the farmers. Hence, farmers are likely to adopt more. This echoes with the findings of Nnadi and Akwiwu (2005) and Singh et al. (2000). Coefficient of farmer's age was negative and significant at $10 \%$ level of significance. If age of farmers' increases by 1 year, keeping other factors constant, adoption would be decreased by 0.19 units. It implies that younger farmers were more interested to adopt new production technologies.

Table 11. Factors affecting the adoption of wheat production practices

\begin{tabular}{llll}
\hline Variable & Co-efficient & Standard error & t-value \\
\hline Constant & $1.96^{* * *}$ & 0.280 & 6.99 \\
Education & $0.166^{* *}$ & 0.069 & 2.38 \\
Age & $-0.193^{*}$ & 0.127 & -1.82 \\
Experience & $0.024^{*}$ & 0.015 & 1.58 \\
Farm size & -0.021 & 0.048 & -0.431 \\
Household size & -0.010 & 0.032 & -0.317 \\
Extension contact & $0.521^{* * *}$ & 0.049 & 10.51 \\
Adjusted R & 0.51 & & \\
F-value & $21.73^{* * *}$ & & \\
Observations & 110 & & \\
\hline
\end{tabular}

Note: $*$, ** and $* * *$ indicates significant at $10 \%, 5 \%$ and $1 \%$ level of significance 


\section{Problems of adoption}

Table 12 shows the seriousness of problems that hinder adoption of wheat production practices. Almost $90 \%$ of the farmers indicated inadequate information media as a problem of adoption in the study areas. Mean score of this problem was 2.07, which indicated that it is a serious problem. In this context, extension communication can

Table 12. Problems of adoption in the study areas

\begin{tabular}{lccccccc}
\hline Problems & VS & S & MS & LS & NS & Mean & Remarks* \\
\hline Inadequate medium as a & 27 & 18 & 12 & 42 & 12 & \multirow{2}{*}{2.07} & Serious \\
source of information & $(24.55)$ & $(16.36)$ & $(10.91)$ & $(38.18)$ & $(10.91)$ & & \\
Lack of technical & 14 & 37 & 16 & 33 & 9 & \multirow{2}{*}{2.11} & Serious \\
knowledge & $(12.73)$ & $(33.64)$ & $(14.55)$ & $(30.00)$ & $(8.18)$ & & Less \\
Lowlevel of income & 11 & 29 & 34 & 18 & 17 & 1.97 & Serious \\
& $(10.00)$ & $(26.36)$ & $(30.90)$ & $(16.36)$ & $(15.45)$ & & Less \\
Lack of access to credit & 9 & 36 & 18 & 25 & 20 & 1.86 & serious \\
facilities & $(8.18)$ & $(32.73)$ & $(16.36)$ & $(22.73)$ & $(18.18)$ & & Less \\
Fear \& suspicion & 1 & 5 & 5 & 18 & 79 & 0.43 & serious \\
& $(0.91)$ & $(4.55)$ & $(4.55)$ & $(16.36)$ & $(71.82)$ & &
\end{tabular}

Note: Figures in parentheses indicates percentage of total

$\mathrm{VS}=$ Very serious, $\mathrm{S}=$ Serious, $\mathrm{MS}=$ Moderate serious, $\mathrm{LS}=$ Less serious, $\mathrm{NS}=$ Not serious

$*$ The midpoint of this frequency table is 2 . As a decision rule, any mean score that is $\leq 2=$ less serious and that $>2=$ serious

\section{Conclusion and Recommendations}

Findings of the study suggested that remarkable gaps existed in the application of various technologies in wheat cultivation. Adoption level of seed rate, Urea, TSP, MoP was found to be very low whereas the adoption of sowing time and number of irrigation was found to be high. Different factors like education, age and extension contact had positive and significant effect on the adoption of wheat production practices. Inadequate medium of information, lack of technical knowledge impede the adoption of wheat production practices in the study areas. If the adoption gaps of some of the recommended technologies are properly eliminated, farmers could receive maximum return. Regular visit by extension agencies to disseminate modern production technologies, training to improve technical knowledge, credit with low interest can play a vital role in this regards. Besides, more research must be done to define appropriate wheat research priorities in the country.

\section{References}

Baksh, M.E., Kabir, MJ. and Kispatta, K. 2009. Socio-economic assessment of wheat variety Shatabdi in some selected areas of Bangladesh. Bangladesh J. Agril. Res. 34 (2): 215-226.

BBS. 2010. Year book of Agricultural Statistics of Bangladesh, Bangladesh Bureau of Statistics, play a vital role. Lack of technical knowledge was also a serious problem that hinders the adoption of wheat production practices. Low level of income, lack of access to credit facilities and fear \& suspicion were identified as less serious problem since the mean score were 1.97, 1.86 and 0.43 respectively.
Ministry of Planning, Dhaka, Bangladesh. $129 \mathrm{p}$.

Dixon, J., Nalley, L., Kosina, P., La Rovere, R., Hellin, J. and Aquino, P. 2006. Adoption and economic impact of improved wheat varieties in the developing world. J. Agril. Sci. 144 (6): 489- 502.

Edna, C. Matthews-Njoku, Adesope, O.M. and Iruba, C. 2009. Acceptibility of improved crop production practices among rural women in aguata agricultural zone of Anambra State, Nigeria. African J. Biotech. 8 (3): 405-411.

Feder, G., Just, R.E. and Zilberman, D. 1985. Adoption of agricultural innovations in developing countries. Econ. Dev. \& Cultural Change. 33 (2): 255-298.

Gardebroek, C. 2006. Comparing risk attitudes of organic and non-organic farmers with a bayesian random coefficient model. European Review of Agril. Econ. 33: 485510.

Hossain, A.B.S. 1984. Wheat production in Bangladesh: its constraints and research priorities, In: Proc. of the International symposium on wheat for more tropical environments, Mexico D.F. pp. 59-62.

Hossain, S.M.A. and Bruce, R.C. 1992. Patterns and determinants of adoption of farm practices: some evidence from Bangladesh. Agril. System. 38 (1): 1-15.

Iqbal Muhammad, M., Azeem Khan and Munir Ahmed. 2002. Adoption of recommended 
varieties: a farm level analysis of wheat growers in irrigated Punjab. The Pakistan Dev. Review. 41 (1): 29-48.

Kamruzzaman, M., Fakhrul Islam, S.M., Begum, M.A.A., Shiblee, S.M.A., Kibria, M.G. and Ray, S.K. 2001 Adoption level of wheat technology and the grower's knowledge gap in Bangladesh. Pakistan J. Biol. Sci. 4(1): 1-6.

Krishi Projokti Hatboi. 2006. An Hand book of Agro-technology, $4^{\text {th }}$ edition, Bangladesh Agricultural Research Institute, Gazipur, Bangladesh. pp. 13-14.

Lee David, R. 2005. Agricultural sustainability and technology adoption: Issues and policy for developing countries. American J. Agril. Econ. 87 (5): 1325-1334.

Mittal Surabhi and Praduman Kumar. 2000. Literacy, technology adoption, factor demand and productivity: An econometric analysis. Indian J. Agril. Econ. 55 (3): 490499.

Nnadi, F.N. and Akwiwu, C.D. 2005. Rural women's response to selected crop production technologies in Imo State Nigeria. Global Approaches Ext. Pract. 1(1): 47-52.

Pandit, D.B., Baksh, M.E., Sufian, M.A., Harunur-Rashid, M. and Islam, M.M. 2007. Impacts of participatory variety selection in wheat on agro-economic changes of wheat farmers in Bangladesh. Bangladesh J. Agril. Res. 32 (3): 335-347.

Sanchez, P.A., Denning, G.L. and Nziguheba, G. 2009. The African green revolution moves forward. Food Security. 1: 37-44.

Serra, T., Zilberman, D. and Gil, J.M. 2008. Differential uncertainties and risk attitudes between conventional and organic producers, the case of Spanish COP farmers. Agril. Econ. 39 (2): 219-229.

Singh, K., Singh, J.P. and Singh, P. 2000. Adoption behaviour of small farmers in Bharatpur district of Rajasthan. J. Agril. Sci. Res. 36: 51-56.

Singh, M. and Chahal, S.S. 2009. A study on the extent of adoption of various recommended technologies in wheat cultivation in Punjab. Agril. Econ. Res. Review. 22: 349-354.

Walford, N. 2002. Agricultural adjustment: adoption of and adaptation to policy reform measures by large-scale commercial farms. Land Use Policy. 19: 243-257.

Wanyama, J.M., Nyambati, E.M., Mose, L.O, Mutoko, C.M., Wanyonyi, W.M. Wanjekeche, E. and Rono, S.C. 2010. Assessing impact of soil management technologies on smallholder farmers' livelihoods in North Western Kenya. African J . Agril. Res. 5 (21): 2899-2908. 